\title{
Morphological Description of Calcareous Nannofossils Assemblage of a Middle-Miocene to Late-Miocene Section in the Niger-Delta, Nigeria
}

\author{
Peter Sunday Ola \\ Federal University of Technology, Akure, Nigeria \\ Email: psola@futa.edu.ng
}

How to cite this paper: Ola, P.S. (2018) Morphological Description of Calcareous Nannofossils Assemblage of a Middle-Miocene to Late-Miocene Section in the Niger-Delta, Nigeria. Open Journal of Geology, 8, 925-937.

https://doi.org/10.4236/ojg.2018.89055

Received: May 15, 2017

Accepted: June 5, 2017

Published: August 27, 2018

Copyright $\odot 2018$ by author and Scientific Research Publishing Inc. This work is licensed under the Creative Commons Attribution International License (CC BY 4.0).

http://creativecommons.org/licenses/by/4.0/ (c) (i) Open Access

\begin{abstract}
Forty four (44) different forms of nannofossils recovered from the middle-Miocene to late-Miocene sediments of a section $((8900-11,000) \mathrm{ft}(2713$ $3353 \mathrm{~m})$ ) of a well in the prolific oil producing Niger delta, Nigeria were described and grouped into twelve, though not on phylogenetic relationship, for documentation purpose. The standard strewn-slide technique was used to recover the fossils. The aim is to present the distinguishing morphological features of each of the nannofossils group. Of the recovered forms Genus, Discoaster, was found prominent and divisible into six sub-groups: 6-rayed discoaster with bifurcations, 6-rayed discoasters without bifurcation, 5-rayed discoasters, 5-rayed discoaster with acute bifurcations, 5-rayed nannolith and the indeterminate forms. Genus Sphenolithus recovered is also divisible into two: species without prominent apical spines and species with prominent, monocrystalline apical spines. Other genera found and described are Catinaster, Cyclicargolithus, Coccolithu, Minylitha, Syracosphaera, Helicosphaera, Pontosphaera, Calcidiscus and Reticulofenestra. All the nannofossils fall within NN11, NN10, NN9, NN8 and NN5 zones belonging to the Middle-Late Miocene age.
\end{abstract}

\section{Keywords}

Nannofossils, Morphology, Niger Delta, Discoaster, Sphenolithus, Miocene

\section{Introduction}

Until recently, published biostratigraphic information on the prolific oil producing Niger delta were based mainly on palynomorphs and foraminiferal un- 
like nannofossils [1] [2] [3] [4] [5]. Such publications include [5] [6] [7] [8] [9]. This could be attributed to the proprietary nature of the data of the oil companies that contract out routine nannofossil biostratigraphic works. The use of nannofossils for biostratigraphic studies has increased greatly because of their unique microscopic size and the age range of many of its species that make them serve as index fossils as well as the speedy processing techniques of samples that yield rapid and excellent results. Refinement of an existing chronostratigraphic scheme of various oil companies in Nigeria to levels of accurately tying local sequence to regional and global bio- and chronostratigraphic schemes is still ongoing. This requires the use of nannofossils' results in addition to the traditional use of foraminiferal and other palynomorphs.

This work aims at presenting the morphological features of some nannofossils group recovered from a section of a well in the Niger delta. The morphological groups constitute neither a classification nor an attempt to organize possibly phylogenetically related forms under the same heading. The goal is to point out the distinguishing features of forms within each group for documentation purpose. Although the samples are recovered from the Agbada Formation no emphasis is laid on their biostratigraphic and paleoclimatic significance. Of note is the use of the ratio of D. brouweri and Coccolithus pelagicus, which are common in this study, for paleoclimatic studies [10]. It is envisaged that the knowledge from this offshore study could provide a clue to the age of some nannofossil assemblages without major index markers found in some onshore well sequences in the Delta.

\section{Regional Geological Setting}

To date the Niger Delta is perhaps the most important sedimentary basin in Sub-Sahara Africa in terms of petroleum production. It covers an area of about 75,000 square kilometers on the continental margin of the Gulf of Guinea in equatorial West Africa between latitudes $3^{\circ} \mathrm{N}$ and $6^{\circ} \mathrm{N}$ and longitudes $5^{\circ} \mathrm{E}$ and $8^{\circ} \mathrm{E}$ (Figure 1). The evolution of the Niger Delta followed the separation of the South American from the Africa plate during Mesozoic break up of Gondwanaland [11].

Three major lithostratigraphic units make up the Cenozoic Niger Delta. They are: a sequence of over-compacted over pressured pro-delta marine shales, named Akata Formation; which is overlain by a paralic sequence of alternating sands and shales, named Agbada Formation; and finally covered by continental sands and gravels of Benin Formation (Figure 2). These units are strongly diachronous becoming younger in age from the north (Eocene) to the South (Recent) and were built up by the imbricated super position of numerous offlap cycles [12]. Progressive outbuilding of the delta into the sea is shown by a shift in the inferred positions of the coastline from Eocene to the present.

Presently the Cenozoic Niger Delta is a large, high-energy arcuate delta of the destructive, wave-dominated type divisible into offshore and onshore (Figure 1). 


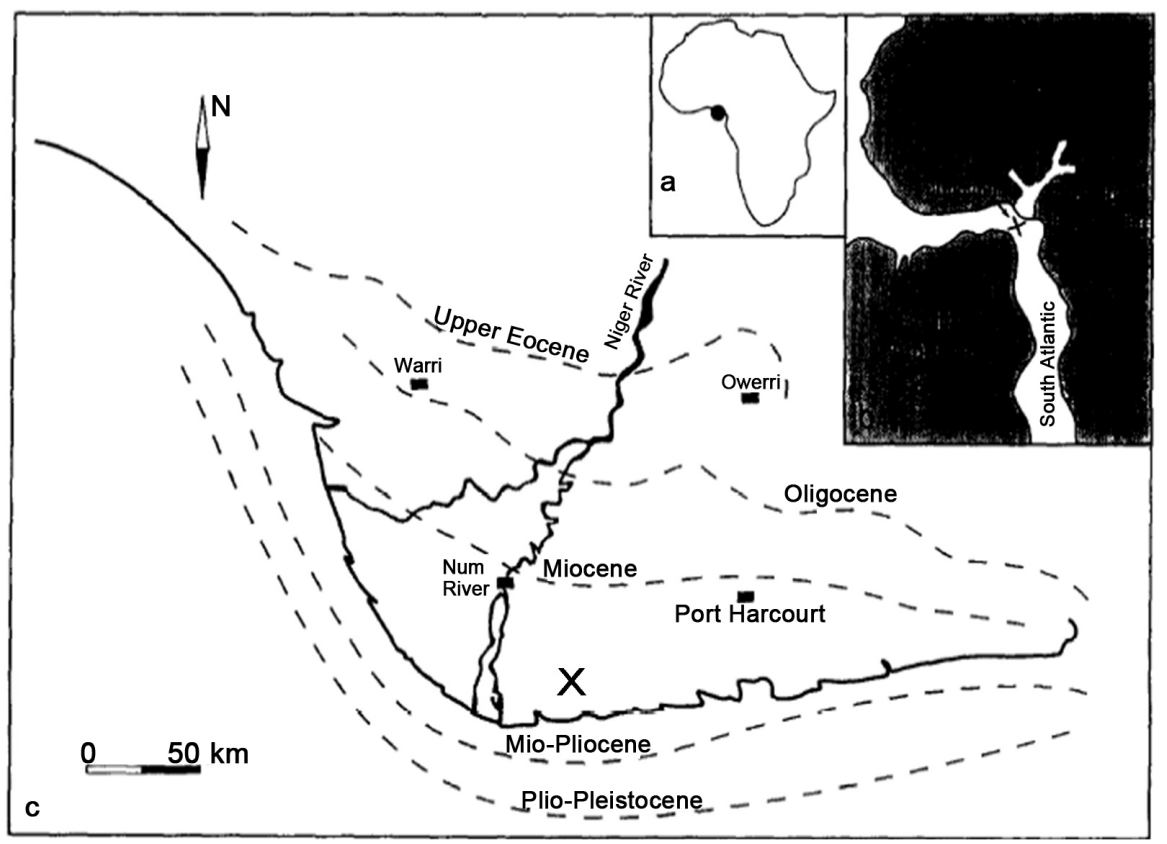

Figure 1. Location of the Niger delta oil province. The approximate location of well 1 is marked X.

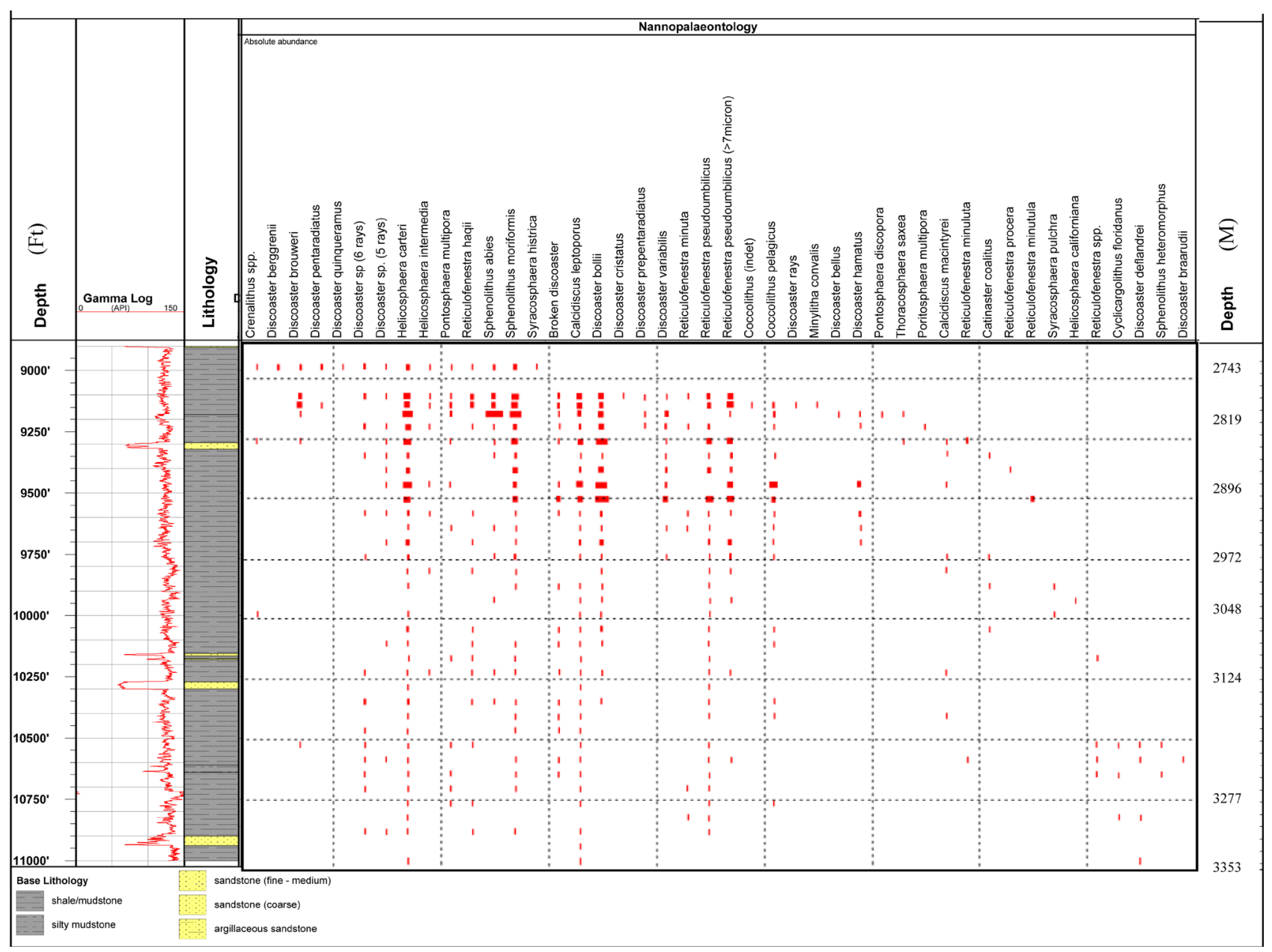

Figure 2. Distribution pattern of the described nannofossils of a Middle-Miocene to Late-Miocene Section in the Niger-Delta, Nigeria. 
The changes in the stratigraphy of the Akata shale have been described from inboard to ultra-deepwater as a time-transgressive series of Lower Tertiary prodelta and marine shales that prograded from onshore Nigeria to ultra-deep water areas. The outbuilding and general geology are contained in several publications including [13].

\section{Materials and Methods of Study}

The technique used to retrieve the forms described in this study follows the standard strewn-slide technique of [14]. Two to four (2 - 4) grams of fresh shale was carefully selected from each of the 35 composite ditch cutting samples recovered within a section (8900 - 11,000 feet) of an offshore Niger delta oil well. Oily samples from oil based drilling mud were gently washed with domestic detergent to remove drilling mud. Each of the samples was put on a clean white sheet of paper, which folded, and then gently crushed because of the fragile nature of nannofossils using pestle. The crushed materials were then dispersed in distilled water inside a glass vial and stirred with a stirring rod after which it was decanted in another glass tube. Using a disposable pipette, the resulting suspension was pipetted onto a $22 \times 40 \mathrm{~mm}$ cover slip, then placed on a hot plate and gently dried at a temperature of approximately $50^{\circ} \mathrm{C}-60^{\circ} \mathrm{C}$. Thereafter, cover slip was then mounted on a labeled glass slide using two drops of Norland optical adhesive mounting medium and then cured under the ultra violet light for forty five minutes. The prepared slides were examined for their calcareous nannofossils' content under a high powered Olympus light microscope in cross-polarized and transmitted light. About three (3) traverses are studied in each slide. The numbers of different species found were recorded to get its known Abundance and Diversity. Detailed identification of the assemblages and description are basically based on previous works of [15] [16] [17] and other relevant texts mentioned in the discussion section. Photographs of the forms were taken using an OLYMPUS CX31PF binocular microscope with camera attachment.

\section{Result}

From the section studied, 44 different forms were recovered. Of all these forms, the following are the marker species identified: Discoaster quinqueramus, Discoaster bergrennii, Discoaster bollii, Discoaster hamatus, Discoaster prepentaradiatus, Reticulofenestra pseudoumbilicus ( $>7$ microns), Catinaster coalitus, Sphenolithus abies, Sphenolithus heteromorphus, Minylitha convalis. Absolute abundance of all the forms recovered shows dominance of Sphenolithus abies, Sphenolithus moriformi and Discoaster bollii and their acme events (Figure 2). On the distribution chart (Figure 2) it is significant to note that the general abundance and diversity of the forms decrease with depth within the studied section. Minylitha convallis occurs only in one sample (Figure 2). 


\section{Discussion}

\subsection{Morphology}

Generally the forms recovered from the studied well are herein grouped into twelve genera: Discoaster, Catinaster, Helicosphaera [18], Pontosphae, Syracosphaera [19], Cyclicargolithus, Reticulofenestra, Coccolithus, Calcidiscus, Minylitha, Sphenolithus and Thoracosphaera. Each of the group is further divided into sub-groups based on some minor morphological differences. These morphological differences are briefly discussed in this section, commonly in line with [20].

\subsubsection{Genus: Discoaster}

The genus fund in this study could further be grouped into six thus:

\section{1) 6-Rayed Discoaster with Bifurcations}

This is the predominant group of Neogene discoasters [20]. However asymmetric 5-rayed specimens of all these species occasionally occur [20]. Discoasters found during analysis that fall in this group include:

a) D. bolli (Plate 1, photograph numbers: 11, 12 and 13)

Description: This species has relatively short arms bifurcating into terminations in different planes. Both sides of the large central area have a stellate stem, one small, one large, a structural element which distinguishes $D$. bollii from any other species of otherwise somewhat similar appearance. According to [21], it is similar to Discoaster exilis but with large distal boss, wide central-area, and usually smaller $(<10 \mu \mathrm{m})$ [20].

\section{b) D. variabilis}

Description: This form was described by [20] as having a central area with proximal and distal ridges; the small size of the bifurcations indicates its failure to develop bifurcating arms. It usually has 6 , sometimes 5 and rarely 4 or 3 arms and a stellate central knob with the tips of the star extending to the margin between the arms on one side and along the median line of the arms [22] on the other (concave) side. The arms terminate with a bifurcation forming an angle of about $90^{\circ}$, which is more or less filled with an additional web. The arms themselves are parallel-sided or slightly tapering and the inter-arm area is $\mathrm{V}$-shaped. $D$. variabilis differs from $D$. deflandrei by the $\mathrm{V}$-shaped inter-arm area, the longer arms and the web between the bifurcated ends of the arms.

c) D. deflandrei (Plate 1, photograph number; 17)

Description: [20] describes the central-area as wide and rather featureless. It has short rays and wide bifurcations and that asymmetric 5 and 7-rayed forms do occur.

\section{2) D. brouweri Group}

These are 6-rayed discoasters without bifurcation, which are closely related to $D$. brouweri with fewer rays [20]. The following discoasters fall in this group:

a) D. braarudii. It is described by [23] as been similar to $D$. brouweri but their ray-tips (tips of arm) are simple without proximal extensions [20]. 


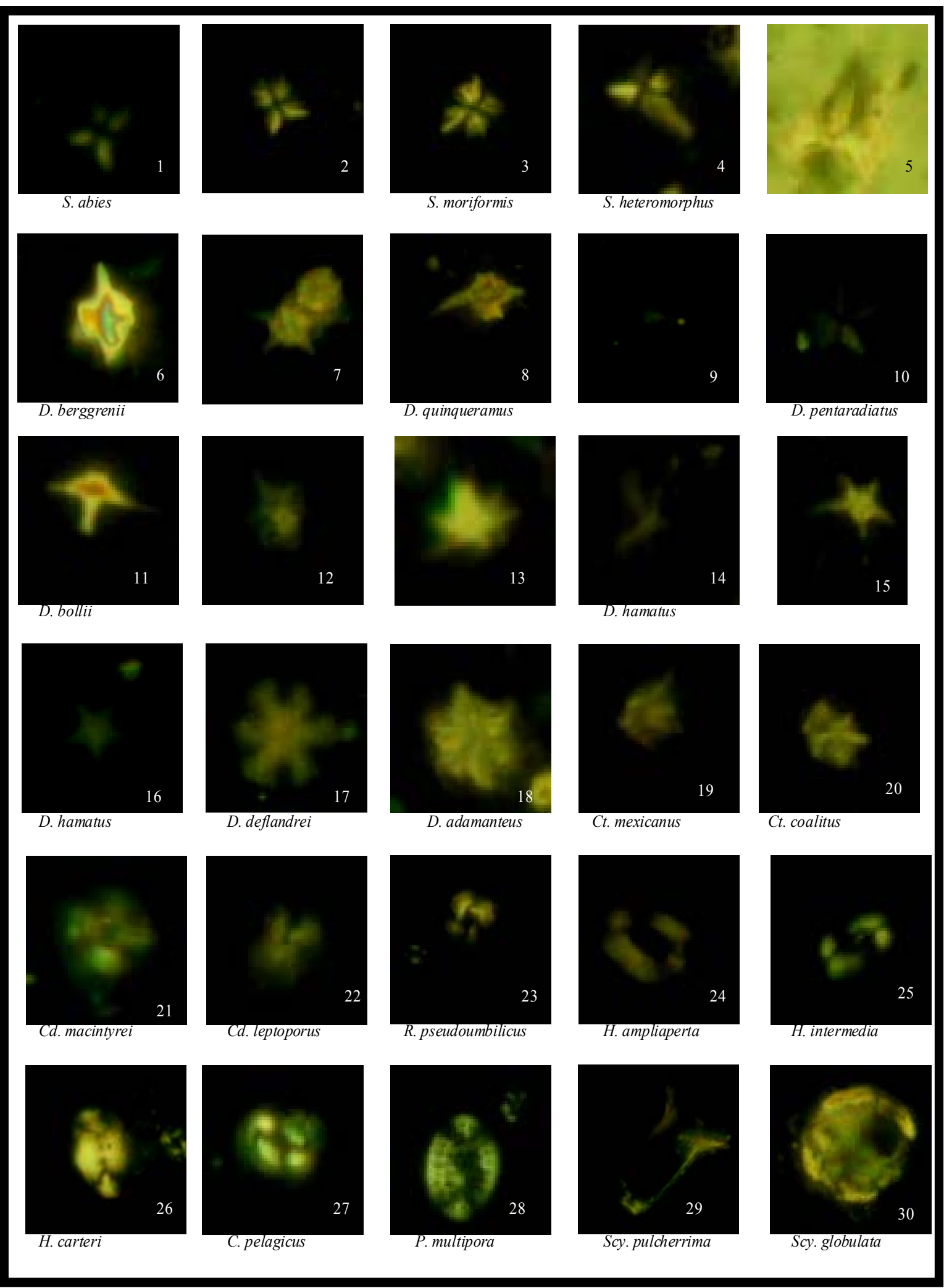

Sphenolithus (S.), Discoaster (D.), Catinaster (Ct.), Calcidiscus (Cd.), Reticulofenestra (R.),

Helicosphaera (H.), Coccolithus (C.), Pontosphaera (P.), Scyphosphaera (Scy.).

Plate 1. Photomicrographs of Some of the Forms Recovered in well A1, Niger delta, Nigeria. 
N.B. Discoasters with this general morphology also often occur through dissolution or poor development of other species e.g. D. exilis, D. brouweri [20].

b) D. brouweri

c) Description: This is a 6-rayed discoaster without bifurcation. This form has been to include forms with usually 6 long arms that bend down like umbrella ribs with or without a central knob on the concave side [20].

It differs from other 6-armed forms by the absence of any bifurcation or sideward bending of the tips of the arms.

\section{3) Symmetric 5-Rayed Discoasters}

The followings were identified within this group:

\section{a) D. quinqueramus}

Description: According to [24], D. quinqueramust has 5 tapering, long non-bifurcating arms arranged symmetrically and a robust central area with a very prominent, 5 -armed central knob. Early forms are difficult to distinguish from the older $D$. berggrenii, which features an even more prominent central knob and shorter arms. Other 5-armed species either have bifurcating arms and/or no prominent central knob or bending arms.

Range: NN11 [25] which is equivalent to CN9 [26].

b) D. berggrenii (Plate 1, photograph numbers: 6 and 7)

Description: This form is similar to $D$. quinqueramus but with a central area that is two times wider. It is a symmetric, 5 armed form with tapering arms and a very prominent knob consisting of the inwardly directed prolongations of the ridges on the arms on one side and of ridges extending from the inter-arm area over a depressed central area to form a central knob (CSEM in [17]) on the other side. The free length of the arms is about equal to the diameter of the central area [24].

4) a) D. pentaradiatus (Plate 1; photograph number: 10)

Description: In [20] [26] described it as a 5-rayed discoaster with acute bifurcations, strongly concavo-convex and birefringent (each ray is a separate crystal-unit, with c-axes inclined slightly from vertical toward radial), this was later amended by [24] as having 5 thin, tapering arms with a terminal bifurcation which characteristically is thin and delicate (and therefore, often broken off) and shows slight birefringence when viewed between crossed nicols [24]. It also shows only little of the umbrella-like bending of $D$. brouweri, from which it differs by also having 5 instead of 6 arms. D. prepentaradiatus is flatter than $D$. pentaradiatus and has shorter and more robust bifurcations [20].

b) D. hamatus (Plate 1, photograph numbers: 14, 15, and 16)

Description: It is a large, symmetric, 5 rayed form with a small knob in the centre. The arms are long, somewhat curved, and turn sharply clockwise and downward near the end, as viewed on the convex side. A much smaller knob is usual as a bifurcation, although it appears to be a continuation of the main part of the arm as it extends in the same direction. D. hamatus differs from D. neo- 
hamatus and $D$. calcaris by having only 5 arms instead of 6 . The other two species have tapering and terminally bent arms.

Range: NN9

\section{5) D. prepentaradiatus}

D. prepentaradiatus is described as a 5-rayed nannolith with broad bifurcations, it is planar and non-birefringent [20].

Range: NN9-NN10

\section{6) Indeterminate Forms}

Unidentifiable/Broken discoasters fall under this group. They are usually common, and for biostratigraphic precision, it is best to record them as such. In addition, isolated rays and pairs of rays are common; care is sometimes needed to avoid misidentifying these.

\subsubsection{Genus: Catinaster}

As described by [21], this form is basket shaped nannolith formed by fusion of the bifurcations of a small discoaster [20].

\section{Range: NN8-NN10}

1) C. coalitus: (Plate 1, photograph number: 20 )

Description: They have their 6 rays confined to basket and according to [20] short pseudo-rays are often formed where the tips of bifurcations meet. C. coalitus holotype is nearly circular and many specimens that are usually assigned to it are hexagonal in outline. These forms are somewhat smaller and are found in the older part of the short range of $C$. coalitus in the Middle Miocene.

\subsubsection{Genus: Helicosphaera [18]}

The Helicosphaera identified in this study include:

\section{1) $H$. carteri (Plate 1, photograph number: 26)}

This is the most common Helicosphaera species. It is medium to large in size and flange ends in wing with two pores in central-area.

Range: NN1-NN21

2) $H$. intermedia (Plate 1, photograph numbers: 25)

Description: According to [25], it is like $H$. euphratis but with the central-area open, spanned by curved and disjunctive bar [20]. The Helicoliths of Helicosphaera intermedia are symmetrically elliptical with a wing that terminates gradually at the beginning of the metapterygal side. The proximal plate is of type II with a large central opening transversed by a sigmoid bridge, which is inclined in a normal direction. A diagonal suture divides the bridge into two roughly triangular segments consisting of equidimensional elements without apparent orientation. The suture of the bridge is visible only in proximal view. The blanket covers the entire distal surface of the helicolith. The ratio of the double edge to the single edge is approximately 3:1. It is S-shaped and its first occurrence is in the Oligocene zone CP16.

\subsubsection{Genus: Pontosphaera}

They are coccoliths whose central areas have variable number of perforations. 
i.) P. multipora (Plate 1, photograph numbers: 28 )

Description: Its central area protrudes above rim, 3 or more cycles of large pores in other words, its floor are pierced by many perforations or thinned by large depressions.

Range: Paleogene-NN21

\section{2) P. discopora}

Description: The rim is elevated with 3 or more cycles of pores.

\subsubsection{Genus: Syracosphaera Lohmann, 1902}

This genus is responsible for much of the diversity of modern coccolithophores ( $>50$ species) but most species produce small coccoliths with low preservation potential and which are difficult to identify under the microscope [20]. The ones identified in this well are the common larger $(>3 \mu \mathrm{m})$ species. They are:

1) S. pulchra (Plate 1, photograph number: 29 )

Description: It is a coccolith with an oblong or irregularly elliptical with bright rim and central-area of radial laths showing tangential c-axis orientation [20].

Range: Paleogene-NN21

\subsubsection{Genus: Cyclicargolithus}

These are forms which have circular to sub-circular central area [20].

1) C. floridanus. They are common forms with sizes usually less than $10 \mu \mathrm{m}$.

\subsubsection{Genus: Reticulofenestra}

They are circular to elliptical in shape with an opened or closed central-area and no special structures.

1) R. pseudoumbilicus (>7 micron): (Plate 1, photograph number: 23)

Description: The size of the central opening is relatively large and greater than 7 micron.

\section{2) R. haqii}

Description: Distinguished by the size of the central opening of size 0.1 to 1.5 $\mu \mathrm{m}$ (micron meters).

\section{3) $R$. minuta}

Description: Used for forms smaller than $3 \mu \mathrm{m}$ ( 3 micron meter).

Range: Paleogene-NN21 i.e. it ranges from the early Oligocene through the Pliocene.

\section{4) R. minutula}

Description: Used to describe forms that range between 3 - $5 \mu \mathrm{m}$.

Range: NN15-NN18

\subsubsection{Genus: Coccolithus}

1) C. pelagicus (Plate 1, photograph number: 27)

Description: The size ranges between $3-16 \mu \mathrm{m}$ and has a central-area open or with transverse bar. 
Range: Paleogene-NN21

\subsubsection{Genus: Calcidiscus}

Calcidiscus recovered from this study have circular to sub-circular proximal shield and are birefringent and the distal shields are non-birefringent with curved sutures. Shields are easily separated [20]. They include:

1) C. leptoporus (Plate 1, photograph number: 22)

Description: [20] described this form as being circular to sub-circular, closed central-area, default name covering a wide range of variation. It is fan shaped and has a closed central slit.

Range: NN2-NN21

2) C. macintyrei (Plate 1, photograph number: 21)

Description: Large placoliths with sub elliptical outline and an elliptical tube which has a relatively large opening and usually lacks calcareous central filling. The placoliths have a non-birefringent distal shield and a birefringent proximal one as the extinction bands of the birefringent proximal shield curve sinistrally in proximal view.

Range: NN7-NN19, but usually only distinguished in the Upper Pliocene and Quaternary [20].

\subsubsection{Genus: Minylitha}

\section{1) M. convallis}

Description: This form has a Rhomb-shaped nannoliths with elevated rim [20]. In other words, it's a thick plate-like individual calcite element with polygonal outline, depressed central area, and raised rim. It appears only moderately bright in polarized light as it is the only species of the Minylitha family.

Range: NN9-NN11A

\subsubsection{Genus: Sphenolithus}

Two groups of this were recovered:

1) Species without prominent apical spines

a) Sphenolithus abies (Plate 1, photograph numbers: 1 and 2)

Description: A representative of the latter type of the sphenoliths distinguishable by its wide proximal shield. It is slightly conical in shape and can be viewed parallel to crossed nicols and also at $45^{\circ}$ to crossed nicols. According to [20], it is similar to $S$. moriformis but more elevated and with cupsate outline.

Range: NN7-NN15

b) S. moriformis (Plate 1, photograph number: 3)

Description: Generalized form with no spine, and upper and lower parts of similar size. It has an obtuse proximal column.

Range: Lower Eocene-NN10

1) Species With Prominent, Monocrystalline Apical Spines [20].

a) S. heteromorphus (Plate 1, photograph numbers 4 and 5)

Description: This form has well developed apical spine. Both Its lateral ele- 
ments and proximal elements are large.

Range: NN4-NN5

\subsubsection{Genus: Thoracosphaera}

1) Thoracosphaera spp.

Description: Some of the species assigned to the Thoracosphaera are calcareous dinoflagellates. The width, shape and outline of archaeopyle vary in the various species. Also, the skeletal ultrastructure showing size, shape and arrangement of skeletal elements in the species vary with the test size which is used with some reservations, is spherical and prolate spheroidal.

Crenalithus spp.

Description: This form belongs to the Crenalithus family.

\subsection{Age Determination}

Considering the age range of the recovered taxa from a section of a well in the Coastal depobelt of Niger delta, the following nannofossil zones could be defined: NN11, NN10, NN9, NN8 and NN5. Zone NN11 which is late Miocene belongs to the Messinian stage. Zones NN10 (Late Miocene), NN9 (Late Miocene) belong to the Tortonian stage, NN8 (Middle Miocene) belong to the Serravallian stage, NN5 (Middle Miocene) belong to the Langhian stage based on [25] All these ages fall within Middle-Late Miocene ages.

\section{Conclusion}

In this study the Genus, Discoaster, was found divisible into six sub-groups: 6-rayed discoaster with bifurcations, 6-rayed discoasters without bifurcation, 5-rayed discoasters, 5-rayed discoaster with acute bifurcations, 5-rayed nannolith and the Indeterminate Forms. Genus Catinaster, Cyclicargolithus, Coccolithu, Minylitha and Syracosphaera have one sub-group each while Helicosphaera, Pontosphaera and Calcidiscus have two and Reticulofenestra four. Two groups of Sphenolithus were recovered. They are species without prominent apical spines and species with prominent, monocrystalline apical spines. All the nannofossils fall within the following zones NN11, NN10, NN9, NN8 and NN5 belonging to the Middle-Late Miocene age.

\section{Acknowledgements}

I am grateful to Global Energy Company Limited, Lagos whose facilities were used for this study. Kayode Aiyemomi and Sola Idris contributed immensely to the processing and interpretation of the data. These are acknowledged with thanks.

\section{Conflicts of Interest}

The authors declare no conflicts of interest regarding the publication of this paper. 


\section{References}

[1] Reyment, R.A. (1963) Studies on Nigeria Upper Cretaceous and Lower Tertiary Ostracoda Part 2, Danian, Paleocene and Eocene Ostracoda. Stockholm Contributions to Geology, 10, 1-286.

[2] Evamy, B.D., Haremboure, J., Karmerlimg, P., et al. (1978) Hydrocarbon Habitat of Tertiary Niger Delta. American Association of Petroleum Geologists Bulletin, 62, 1-39.

[3] Ogbe, F.G.A. (1982) The Biostratigraphy of the Niger Delta, Nigeria. Journal of Mining and Geology, 18, 545-582.

[4] Okosun, E.A. and Lieban, A. (1999) Foraminiferal Biostratigraphy of Eastern Niger Delta, Nigeria. Nigerian Association of Petroleum Explorationist Bulletin, 14, 136-156.

[5] Ozumba, M.B. (1995) Late Miocene-Pliocene Biostratigraphy Offshore Niger Delta. Nigerian Association of Petroleum Explorationist Bulletin, 10, 40-48.

[6] Bassey, C.E. and Alalade, B. (2005) Late Miocene to Pleistocene Planktonic Foraminiferal Biostratigraphy and Palaeoecology of North Apoi C Well, Offshore Western Niger Delta, Nigeria. Journal of Mining and Geology, 41, 97-104. https://doi.org/10.4314/jmg.v41i1.18833

[7] Fadiya, S.L., Jaiyeola-Ganiyu, F.A. and Fajemila, O.T. (2014) Foraminifera Biostratigraphy and Paleoenvironment of Sediments from Well AM-2, Niger Delta. Ife Journal of Science, 16, 61-72.

[8] Boboye, O.A. and Fowora, O. (2007) Biostratigraphy of Calcareous Nannofossils of Well XH-1, Deep Offshore, Niger Delta, Nigeria. Journal of Mining and Geology, 43, 175-186. https://doi.org/10.4314/jmg.v43i1.47903

[9] Ojo, E.A., Fadiya, L.S. and Ehinola, O.A. (2009) Biozonation and Correlation of BDX-1 and BDX-2 Wells of Deep Offshore Niger Delta Using Calcareous Nannofossils. Search and Discovery Article \#50194.

[10] William, G., Siesser, W.G. and De Kaenel, E.P. (1999) Neogene Calcareous Nannofossils: Western Mediteranean Raneanbiostratigraphy and Paleoclimatology. In: Zahn, R., Comas, M.C. and Klaus, A., Eds., Proceedings of the Ocean Drilling Program, Scientific Results, Vol. 161.

http://www-odp.tamu.edu/publications/161_SR/VOLUME/CHAPTERS/CHAP_16. $\underline{\mathrm{PDF}}$

[11] Whiteman, A.J. (1982) Nigeria: Its Petroleum Geology, Resources and Potential. Graham and Trotman, London, Vol. 2, 394. https://doi.org/10.1007/978-94-009-7361-9

[12] Weber, K.J. and Daukorou, E.M. (1975) Petroleum Geology of the Niger Delta. Proceedings of the Ninth World Petroleum Congress, 2, 209-222.

[13] Doust, H. and Omatsola, E. (1990) Niger Delta. In: Edwards, J.D. and Santogrossi, P.A., Eds., Divergent /Passive Margin Basins, AAPG Memoir 48, 201-238.

[14] Bown, P.R. and Young, J.R. (1998) Techniques. In: Bown, P.R., Ed., Calcareous Nannofossil Biostratigraphy, Kluwer Academic Publication, Dordrecht, 16-26. https://doi.org/10.1007/978-94-011-4902-0_2

[15] Martini, E. (1971) Standard Tertiary and Quaternary Calcareous Nannoplankton Zonation. In: Farinacci\}, A., Ed., Proceedings of Second Planktonic Conference, Roma, Tecnoscienza, 739-785.

[16] Backman, J. (1984) Cenozoic Calcareous Nannofossils and Biostratigraphy from the North Eastern Atlantic Ocean-Deep Sea Drilling Project Leg 81. 
[17] Perch-Nielsen, K. (1985) Cenozoic Calcareous Nannofossils. In: Bolli, H.M., Saunders, J.B. and Perch-Nielsen, K., Eds., Plankton Stratigraphy, Cambridge Earth Sciences Series, Cambridge University Press, Cambridge, 427-554.

[18] Kamptner, E. (1931) Nannoconus steinmanni nov. gen. nov. spec., ein merkwûrdiges gesteinsbildenses Mikrofossil aus dem jungeren Mesozoikum der Alpen. Paläontologische Zeitschrift, 13, 288-298. https://doi.org/10.1007/BF03044000

[19] Lohmann (1909) Who Created the Term "Nanoplankton" for Small Plankton, Which Passed through the Mesh of Polyplankton Net $(63 \mu \mathrm{m})$.

[20] Young, J.R. (1998) Neogene. In: Bown, P., Ed., Calcareous Nannofossil Biostratigraphy, Br. Micropaleontol. Soc. Publ., London, 225-265. https://doi.org/10.1007/978-94-011-4902-0_8

[21] Martini, E. and Bramlette, M.N. (1963) Calcareous Nannoplankton from the Experimental Mohole Drilling. Journal of Paleontology, 37, 845-856.

[22] Hojjatzadeh, M. (1978) Discoasters of the Blue Clay (Middle Miocene) of Malta and Gozo. Geological Magazine, 01. https://doi.org/10.1017/S0016756800040942

[23] Bukry, D. (1971) Discoaster Evolutionary Trends. Micropaleontology, 17, 43-52. https://doi.org/10.2307/1485036

[24] Martini, E. (1971) Standard Tertiary and Quaternary Calcareous Nannoplankton. In: Farinacci, A., Ed., Proceedings II Planktonic Conference, Vol. 2, 739-785.

[25] Okada, H. and Bukry, D. (1980) Supplementary Modification and Introduction of Code Numbers to the Low-Latitude Coccolith Biostratigraphic Zonation (Bukry, 1973; 1975). Marine Micropaleontology, 5, 321-325. https://doi.org/10.1016/0377-8398(80)90016-X

[26] Tan, S.H. (1927) Discoasteridae incertae sedis. Proceedings of the Section of Sciences, 30, 411-419. 